\title{
Exploiting the closest productive area: geographical segregation of foraging grounds in a critically endangered seabird
}

\author{
M. Louzao ${ }^{1,2, *}$, J. Navarro ${ }^{3}$, M. G. Forero ${ }^{4}$, J. M. Igual $^{1}{ }^{\text {, M. Genovart }}{ }^{1}$, \\ K. A. Hobson ${ }^{5}$, D. Oro ${ }^{1}$ \\ ${ }^{1}$ Institut Mediterrani d'Estudis Avançats IMEDEA (CSIC-UIB), Miquel Marquès 21, 07190 Esporles, Mallorca, Spain. \\ ${ }^{2}$ Helmholtz Centre for Environmental Research-UFZ, Permoserstraße 15, 04318 Leipzig, Germany \\ ${ }^{3}$ Institut de Ciències del Mar (CSIC), Passeig Marítim de la Barceloneta 37-49, 08003 Barcelona, Spain \\ ${ }^{4}$ Departamento de Biología de la Conservacíon, Estación Biológica de Doñana (CSIC), Apartado 1056, 41013 Sevilla, Spain \\ ${ }^{5}$ Environment Canada, 11 Innovation Blvd., Saskatoon, Saskatchewan S7N 3H5, Canada
}

\begin{abstract}
While breeding, seabirds are limited to exploiting resources within a restricted area around their breeding site and should exploit the closest productive marine areas within their distribution range. We investigated this hypothesis in one of the most endangered European seabirds, the Balearic shearwater Puffinus mauretanicus (ca. 3200 breeding pairs), restricted to the Balearic Islands. Our aims were (1) to assess whether isotopic evidence (i.e. stable isotopes of $\delta^{13} \mathrm{C}$ and $\delta^{15} \mathrm{~N}$ ) of foraging habitat partitioning occurs among northern, central and southern populations, (2) to geographically locate population-specific potential foraging grounds along the Iberian continental shelf, and (3) to assess whether oceanographic conditions could explain observed patterns of stable isotopes (SI). SI values showed a latitudinal gradient, with birds from the northern population having lower $\delta^{15} \mathrm{~N}$ and $\delta^{13} \mathrm{C}$ values than central and southern populations. Potential foraging grounds of northern, central and southern populations were centred in Cape Creus, Ebro Delta and Cape La Nao, respectively, results which were supported by habitat models. Oceanographic conditions in each potential foraging ground were different; the northern population used richer, colder and deeper waters compared to the central and southern populations. Chlorophyll $a$ was the main oceanographic variable that explained variation in SI values. We hypothesised that SI differences among Balearic shearwater populations might be a consequence of differences in baseline isotopic values among potential foraging grounds rather than real differences in diet. Our comprehensive study also provides important information for management strategies to conserve this critically endangered shearwater.
\end{abstract}

KEY WORDS: Balearic shearwater - Geographical foraging ground segregation · Habitat modelling · Mediterranean Sea $\cdot$ Oceanography $\cdot$ Puffinus mauretanicus $\cdot$ Stable isotopes

\section{INTRODUCTION}

Pelagic seabirds search widely for food in marine ecosystems and are temporally- and energeticallyconstrained to exploit resources within a restricted area around their nest sites while breeding (Orians \& Pearson 1979, Young et al. 2009). Most pelagic seabird species breed in colonies located on remote islands (Warham 1990), and intra- and inter-specific competi- tion for food might promote trophic resource depletion and ultimately affect breeding success, survival or recruitment (Furness \& Birkhead 1984, Hunt et al. 1986, Grémillet et al. 2004). Recent studies have shown that trophic partitioning exists among sympatric seabird populations and is influenced by the distribution, quality and availability of prey, as well as breeding population size (Grémillet et al. 2004, Forero et al. 2005). Trophic partitioning can operate through habi- 
tat segregation or selection of different prey within the same habitat, with individual factors such as sex and age promoting spatial segregation of foraging grounds (Forero et al. 2005).

Unravelling spatial distribution differences within and among species not only helps to understand the ecological links between the components of marine ecosystems; this also helps to identify conservation gaps relative to human threats (Boersma 2008, Phillips et al. 2009). For example, Young et al. (2009) showed how Laysan albatrosses Phoebastria immutabilis breeding in 2 distant breeding populations in the North Pacific showed differences in patterns of plastic ingestion relative to geographical segregation of foraging grounds. However, studying the at-sea distribution and foraging ecology of marine top predators is difficult because they forage over vast areas, and logistical constraints limit the spatial and temporal coverage of sampling programs. Recent ecological tools such as analysis of stable isotope (SI) analysis (SIA), habitat modelling and ocean remote sensing (Inger \& Bearhop 2008, Louzao et al. 2009) provide new opportunities to investigate the foraging ecology of marine predators. Levels of SIs of nitrogen $\left(\delta^{15} \mathrm{~N}\right)$ and carbon $\left(\delta^{13} \mathrm{C}\right)$ in tissues are good indicators of the trophic level and foraging habitats, respectively, of marine predators (Forero \& Hobson 2003). Moreover, the isotopic variability found in marine species can be explained by specific oceanographic conditions due to habitat preferences (c.f. Phillips et al. 2009) since productive areas related with terrestrial inputs (e.g. river run-offs) might present different isotopic signatures compared to marine-driven productivity areas (e.g. upwelling). Similarly, habitat use models help explain species-habitat relationships through robust mathematical descriptions and can indicate the oceanographic features primarily associated with seabirds (Louzao et al. 2006a). Furthermore, habitat models can be used to predict the most likely pelagic habitats used in both time and space (Guisan \& Zimmermann 2000).

In the present study, we focused on one of the most endangered European seabirds, the Balearic shearwater Puffinus mauretanicus, which breeds only on the Balearic Islands in the western Mediterranean Sea. Due to its small (ca. 3200 breeding pairs) and declining population (7.4\% decrease per year; Oro et al. 2004), this pelagic species is currently listed as Critically Endangered on the IUCN Red List (BirdLife International 2008, Arcos 2011). Balearic shearwaters breed in scattered colonies, ranging from ca. 5 to 300 breeding pairs (Ruiz \& Martí 2004). During breeding, the foraging range of the spe- cies comprises the productive Iberian continental shelf and is influenced by oceanographic processes driving the distribution and availability of their natural prey (Louzao et al. 2006a, Bellido et al. 2008).

Our main aim was to assist conservation efforts by elucidating spatial connections between breeding and foraging grounds. Specifically, our objectives were (1) to assess whether habitat partitioning occurs along the breeding range (northern, central and southern populations) based on SIA $\left(\delta^{13} \mathrm{C}, \delta^{15} \mathrm{~N}\right)$, (2) to locate population-specific potential foraging grounds along the Iberian continental shelf, and (3) to assess whether oceanographic conditions could explain observed patterns of SIs. We expected that Balearic shearwaters make foraging trips between the less productive waters around their breeding colonies and the highly productive waters on the Iberian Mediterranean continental shelf (Louzao et al. 2006a, Louzao et al. 2009). However, marine resources are patchily distributed along this continental shelf system and different mesoscale oceanographic features result in productivity hotspots in the Gulf of Lions, Cape Creus, offshore Barcelona, Ebro Delta and Cape La Nao (Fig. 1; Louzao et al. 2009). Within this context, we predicted that northern, central and southern populations would each exploit the closest productive marine areas within the Iberian continental shelf. We also expected different SI

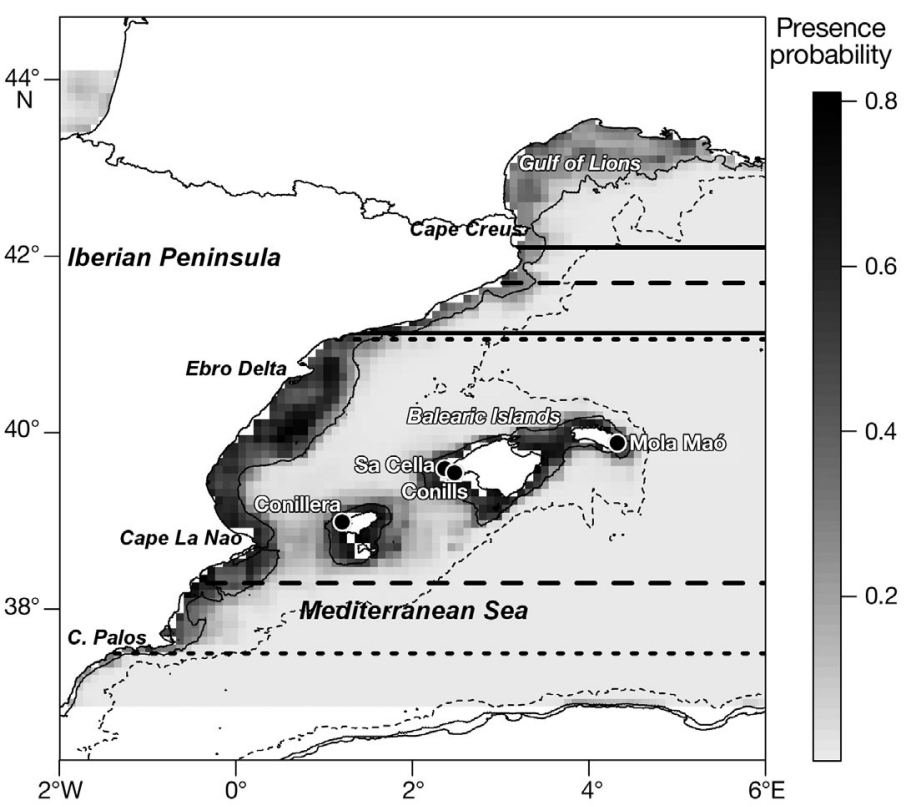

Fig. 1. Puffinus mauretanicus. Study area showing the locations (black circles) of the 4 breeding colonies studied (1 northern, 2 central populations and 1 southern), the presence probability based on the habitat model (Louzao et al. 2006a), and the limits of the potential foraging grounds (PFGs) of northern (solid lines), central (dashed lines) and southern (dotted lines) populations. Depth is represented by the isobaths of $200 \mathrm{~m}$ at the limit of the continental shelf (thin solid line) and $2000 \mathrm{~m}$ (thin dotted line) 
signatures of individuals feeding in different areas, mainly related to water mass characteristics influencing baseline isotopic values (Barnes et al. 2009). The workflow of the present comprehensive ecological study is described in Fig. S1 Supplement 1 at www.intres.com/articles/suppl/m429p291_supp.pdf. Finally, we discussed the implications of our results for the conservation of this species.

\section{MATERIALS AND METHODS}

Sampling procedures. During the breeding period of 2003 , we sampled blood from several adults at 4 breeding populations covering the worldwide breeding range of the Balearic shearwater (Fig. 1, Table 1): one northern population (Mola de Maó on Menorca, MOL), 2 central populations (Sa Cella and Conills on Mallorca, CEL and CON respectively, ca. $18 \mathrm{~km}$ apart) and one southern population (Conillera in Eivissa, EIV). The linear distance between northern and central populations was larger (ca. $200 \mathrm{~km}$ ) than the distance between central and southern populations (ca. $120 \mathrm{~km}$ ). We sampled a total of 29 males and 21 females once at the end of the incubation period (Table 1). For each individual, we took $0.5 \mathrm{ml}$ of blood from the brachial vein. The blood was stored in $70 \%$ ethanol and was used for both molecular sexing and SIA of $\delta^{15} \mathrm{~N}$ and $\delta^{13} \mathrm{C}$. The extraction of lipids was considered unnecessary for blood samples because the lipid component in blood is generally very low (Deuel 1955). For a medium-sized bird such as the Balearic shearwater,

Table 1. Puffinus mauretanicus. Summary of $\delta^{15} \mathrm{~N}$ and $\delta^{13} \mathrm{C}$ values (mean $\pm \mathrm{SD}$ ) in blood of adult Balearic shearwaters during the incubation period of 2003. MOL: northern population from Mola de Maó; CEL: central population from Sa Cella; CON: central population from Conills; EIV: southern population from Conillera

\begin{tabular}{|lccc|}
\hline & $\mathrm{n}$ & \multicolumn{1}{c|}{$\delta^{15} \mathrm{~N}$} & \multicolumn{1}{c}{${ }^{13} \mathrm{C}$} \\
\hline MOL & 15 & $9.33 \pm 0.19$ & $-19.31 \pm 0.04$ \\
Males & 9 & $9.19 \pm 0.31$ & $-19.37 \pm 0.05$ \\
Females & 6 & $9.55 \pm 0.35$ & $-19.19 \pm 0.06$ \\
CEL & 21 & $9.91 \pm 0.12$ & $-18.78 \pm 0.10$ \\
Males & 12 & $9.76 \pm 0.16$ & $-18.86 \pm 0.11$ \\
Females & 9 & $10.12 \pm 0.19$ & $-18.68 \pm 0.17$ \\
CON & 8 & $9.98 \pm 0.16$ & $-19.35 \pm 0.12$ \\
Males & 3 & $10.37 \pm 0.31$ & $-19.01 \pm 0.08$ \\
Females & 5 & $9.74 \pm 0.12$ & $-19.55 \pm 0.11$ \\
EIV & 6 & $10.47 \pm 0.33$ & $-18.67 \pm 0.28$ \\
Males & 5 & $10.61 \pm 0.37$ & $-18.54 \pm 0.31$ \\
Females & 1 & 9.81 & -19.34 \\
\hline
\end{tabular}

the isotope values of the whole blood integrate the dietary information of the previous 3 to $4 \mathrm{wk}$ (Hobson \& Clark 1992). Thus, SI values of adults integrated the diet information over the incubation period.

To test for differences in SI values among breeding populations, we used General Linear Models (GLMs) including SIs as response variables, sex and breeding populations as explanatory variables, and their interactions within the $\mathrm{R}$ environment ( $\mathrm{R}$ Development Core Team 2009). Assuming that both isotopes followed a normal distribution, models were fitted with a Gaussian error distribution (identity link) and were ranked based on their Akaike Information Criteria values corrected for small sample sizes $\left(\mathrm{AIC}_{\mathrm{c}}\right)$. The model with the lowest $\mathrm{AIC}_{\mathrm{c}}$ is considered the best compromise between model deviance and model complexity. When models are within 4 points of $\mathrm{AIC}_{\mathrm{C}}$ they are considered statistically equivalent (Williams et al. 2001). In this case, we chose the most parsimonious model having the lowest number of parameters.

Identifying population-specific potential foraging grounds. To determine whether any isotopic evidence of foraging habitat partitioning was present, we first identified population-specific potential foraging grounds over the Iberian continental shelf based on a theoretical search radius. Second, potential foraging grounds were validated by means of predictive habitat models and those potential foraging grounds were characterised oceanographically. Finally, we applied a resampling procedure to link oceanographic conditions to SI values.

Potential foraging grounds: We established a potential search radius of $250 \mathrm{~km}$, given the dispersal capacities of other Puffinus species. For instance, the maximum flying speed of the closely related Manx shearwater Puffinus puffinus is $50 \mathrm{~km} \mathrm{~h}^{-1}$ (Guilford et al. 2008), which means that Balearic shearwaters would only need $5 \mathrm{~h}$ to travel $250 \mathrm{~km}$ from their nests. Moreover, the maximum foraging range of other Puffinus species does not exceed $300 \mathrm{~km}$ (Powell 2009). The core of each potential foraging ground was established by the minimum distance between each breeding population (MOL, CEL and EIV) and the Iberian shelf edge (200 $\mathrm{m}$ depth) within a potential maximum foraging range of $250 \mathrm{~km}$. Only the geographical location of CEL was considered as representative for central populations, given the short distance between this breeding site and CON. The latitude at which the distance between each breeding population and the shelf edge exceeded $250 \mathrm{~km}$ defined the limits of each potential foraging ground.

Oceanographic habitat models: We overlapped the limits of the potential foraging grounds and predictions of the habitat model of Balearic shearwaters (Louzao et al. 2006a) to assess whether potential foraging 
grounds were highly suitable habitats for each breeding population. The oceanographic habitat of the Balearic shearwater was characterised during the chick-rearing period (May to June) in a previous study along the Mediterranean coast of the Iberian Peninsula (details in Louzao et al. 2006a). Observations of Balearic shearwaters were made during 1999, 2000, and 2002 using standardised strip-transect techniques with a $300 \mathrm{~m}$ strip-width transect band and snapshot counts of flying birds. All Balearic shearwaters observed within the survey transect were recorded. We used a hierarchical modelling approach to identify those environmental variables that most accurately reflected the oceanographic habitat of this species by delineating its foraging range using presence/absence data. The foraging range comprised the frontal systems along the eastern Iberian continental shelf waters (depth $>200 \mathrm{~m}$ ) and areas close to the breeding colonies in the Balearic Islands. Finally, predictive habitat models were used to estimate shearwater occurrence probability in the entire western Mediterranean basin (Fig. 1). Predictive models matched the foraging range described by the observed data and also identified the waters close to the breeding colonies in the Balearic Islands as potentially suitable habitat for the Balearic shearwater. We assumed that Balearic shearwaters visit the same foraging grounds as Cory's shearwaters Calonectris diomedea (Louzao et al. 2009) during incubation and chick-rearing stages.

Oceanographic characterisation of potential foraging grounds: To characterise the foraging grounds, the oceanographic variables that were most relevant from a biological point of view were extracted for the western Mediterranean from online databases provided by the Environmental Research Division, Southwest Fisheries Science Center and US National Marine Fisheries Service (http://coastwatch.pfel.noaa.gov/ coastwatch/CWBrowserWW180.jsp). Dynamic oceanographic variables such as sea surface temperature $\left(\mathrm{SST},{ }^{\circ} \mathrm{C}_{i}\right.$ proxy for water mass distribution) and chlorophyll a concentration (chl $a, \mathrm{mg} \mathrm{m}^{-3}$; surrogate of marine productivity) were extracted from SEAWIFS and PATHFINDER data, respectively. Dynamic variables were obtained for March 2003 to match the SI data for the incubation period that year. Static variables such as bathymetry ( $m$; proxy for coastal versus pelagic domains) were extracted once. All variables were aggregated to match the standard grid of $0.1^{\circ}$ cell size. Additionally, we estimated their spatial gradients by estimating their proportional change (PC) within a surrounding $3 \times 3$ cell $\left(0.1^{\circ} \times 0.1^{\circ}\right)$ grid using a moving window as follows: $\mathrm{PC}=[($ maximum value - minimum value $\times 100] /$ (maximum value). This dimensionless metric expresses the magnitude of change in each habitat variable, scaled to the maximum value (e.g.
Louzao et al. 2009). The spatial gradients of chl $a$ and SST indicate the presence of frontal systems, whereas the gradient of bathymetry reflects the presence of topographic features (e.g. shelf break or seamount). Finally, the 6 environmental variables were extracted over the Iberian continental shelf corresponding to the latitudinal limits of each potential foraging ground. We tested whether the oceanographic conditions of the potential foraging grounds were similar based on the non-parametric Kruskal-Wallis test.

Links between SI values and oceanography: We linked oceanographic variables to the SI values of 15 , 21 and 6 shearwaters sampled from MOL, CEL and EIV, respectively. Only CEL was included as representative of central populations given the relatively short distance between CEL and CON. First, we randomly selected 25 values of the 6 oceanographic variables (SST, chl $a$, bathymetry and their spatial gradients) of the corresponding potential foraging ground (see Supplement 2 at www.int-res.com/articles/suppl/m429 p291_supp.pdf). This value (25) was selected as the minimum sample size necessary to reproduce median values of oceanographic variables in each potential foraging ground (see Supplement 2). Then, we estimated the median value of each oceanographic variable. This first step was repeated, as several SI values were available for each breeding population (e.g. 15 shearwaters were sampled from the northern population, and each shearwater was represented by 2 isotope values, $\delta^{15} \mathrm{~N}$ and $\delta^{13} \mathrm{C}$, totalling 30 values). Second, we linked the median values of oceanographic variables to values of both isotopes of the corresponding population. This procedure was applied to each of the northern, central and southern populations.

We assessed the influence of oceanographic variables on the values of $\delta^{15} \mathrm{~N}$ and $\delta^{13} \mathrm{C}$ of each breeding population based on GLMs. Oceanographic variables were normalised, and strongly 'correlated' $\left(\left|\mathrm{r}_{\mathrm{s}}\right|>0.5\right)$ predictors were identified by means of pair-wise Spearman rank correlation coefficients for avoiding colinearity and related problems with parameter estimations (Zuur et al. 2007). When pairs of predictor variables were strongly correlated, we discarded one of the redundant variables by ranking models with only one variable (fitted with a Gaussian error distribution and identity link) by their $\mathrm{AIC}_{\mathrm{C}}$ value. To assess the effect of oceanographic variables and population on SIs, we used GLMs including SI values as response variables and oceanographic variables as explanatory variables. We also included the quadratic term of oceanographic variables to account for potential non-linear relationships between SIs and explanatory variables, typically found in nature (Quinn $\&$ Keough 2002). Models were ranked based on their $\mathrm{AIC}_{\mathrm{c}}$ values. 


\section{RESULTS}

\section{Isotopic evidence of foraging habitat partitioning}

We only tested the effect of sex in 3 of the breeding populations due to the small number of individuals sampled at the southern population (see EIV in Table 1). The results showed that only breeding site explained the variability in $\delta^{15} \mathrm{~N}$ and $\delta^{13} \mathrm{C}$ values (Table 2). Overall, there was an increase in $\delta^{15} \mathrm{~N}$ values of blood of individuals from northern (MOL) to southern (EIV) populations, with central populations being similar (Table 3). On the contrary, 2 assemblages were

Table 2. Puffinus mauretanicus. Results from the GLM models for $\delta^{15} \mathrm{~N}$ and $\delta^{13} \mathrm{C}$ values in blood of adult Balearic shearwaters during the incubation period of 2003. The southern population (EIV) was not included when testing the sex effect due to small sample size. Models were compared and ranked based on their Akaike Information Criteria values corrected for small sample sizes $\left(\mathrm{AIC}_{\mathrm{c}}\right)$. Selected models are in bold. $\mathrm{np}$ : number of parameters estimated in the model

\begin{tabular}{|lrr|}
\hline Model & $\mathrm{np}$ & $\mathrm{AIC}_{\mathrm{c}}$ \\
\hline$\delta^{15} \mathrm{~N}$ & & \\
Population & $\mathbf{3}$ & $\mathbf{9 5 . 4 2}$ \\
Null & 1 & 95.62 \\
Sex & 2 & 98.50 \\
Population + Sex & 4 & 98.85 \\
Population $\times$ Sex & 6 & 103.66 \\
& & \\
$\delta^{13} \mathrm{C}$ & & $\mathbf{4 7 . 8 5}$ \\
Population & $\mathbf{3}$ & 52.03 \\
Population +Sex & 4 & 54.23 \\
Population $\times$ Sex & 6 & 59.09 \\
Null & 1 & 63.27 \\
Sex & 2 & \\
\hline
\end{tabular}

Table 3. Puffinus mauretanicus. Summary statistics of the selected GLM model in Table 2 for explaining $\delta^{15} \mathrm{~N}$ and $\delta^{13} \mathrm{C}$ values in blood of adult Balearic shearwaters during the incubation period of 2003. Categorical variables were calculated relative to the first category (indicated by null values of the estimated parameter and standard error). See Table 1 for population abbreviations

\begin{tabular}{|lrrrc|}
\hline Variable & $\begin{array}{c}\text { Estimated } \\
\text { parameter }\end{array}$ & SE & $t$ & $\operatorname{Pr}(>|t|)$ \\
\hline$\delta^{15} \mathrm{~N}$ & & & & \\
Intercept & 9.92 & 0.14 & 69.71 & $<0.001$ \\
CEL & 0.00 & 0.00 & 0.00 & 0.000 \\
CON & 0.06 & 0.27 & 0.23 & 0.8228 \\
MOL & -0.58 & 0.22 & -2.63 & $<0.05$ \\
EIV & 0.55 & 0.30 & 1.83 & 0.074 \\
& & & & \\
$\delta^{13} \mathrm{C}$ & & & & \\
Intercept & -18.79 & 0.09 & -206.62 & $<0.001$ \\
CEL & 0.00 & 0.00 & 0.00 & 0.000 \\
CON & -0.56 & 0.17 & -3.25 & $<0.01$ \\
MOL & -0.51 & 0.14 & -3.65 & $<0.001$ \\
EIV & 0.11 & 0.19 & 0.60 & 0.555 \\
\hline
\end{tabular}

identified for $\delta^{13} \mathrm{C}$ values: EIV-CEL and CON-MOL. Individuals sampled in MOL showed lower values of both $\delta^{15} \mathrm{~N}$ and $\delta^{13} \mathrm{C}$ (Tables $1 \& 3$, Fig. 2).

\section{Population-specific potential foraging grounds}

The location of potential foraging grounds differed in relation to breeding site position (Fig. 3). For the northern population, the minimum distance to the continental shelf $(212 \mathrm{~km})$ was at $41.6^{\circ} \mathrm{N}$ and with a narrow latitudinal range on their potential foraging ground located between Cape Creus and north of the Ebro Delta. Even if the latitudinal range were much wider, the cores of the potential foraging grounds of central and southern populations were centred in the Ebro Delta and Cape La Nao at ca. 119 and $69 \mathrm{~km}$ from their breeding sites, respectively.

The probability of presence of shearwaters showed an increasing latitudinal trend from north to south with 2 peaks around Ebro Delta and Cape La Nao, which matched the centres of the potential foraging grounds of central and southern populations (Fig. 4). The potential foraging grounds of 3 breeding populations overlapped with high values of $\mathrm{chl} a$, and the spatial gradients of chl $a$ and SST (i.e. indicative of the presence of frontal systems; Fig. 5). Within the potential foraging ground of the northern population, probability of presence was higher in the southern part, likely corresponding to the presence of the frontal systems in that area (Figs. 4 \& 5). Thus, the probability of presence of shearwaters proved to be useful in confirming that each breeding population exploited their closest productive area.

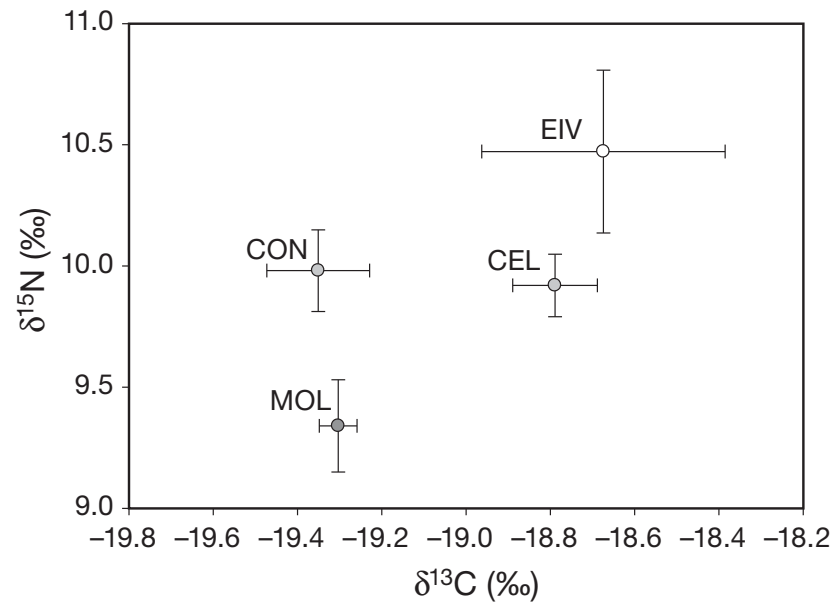

Fig. 2. Puffinus mauretanicus. Mean $( \pm \mathrm{SE})$ stable isotope values of incubating adults from different breeding locations: northern (dark grey MOL), central (light grey CEL, CON) and southern (white EIV) populations. See Fig. 1 caption for population abbreviations 


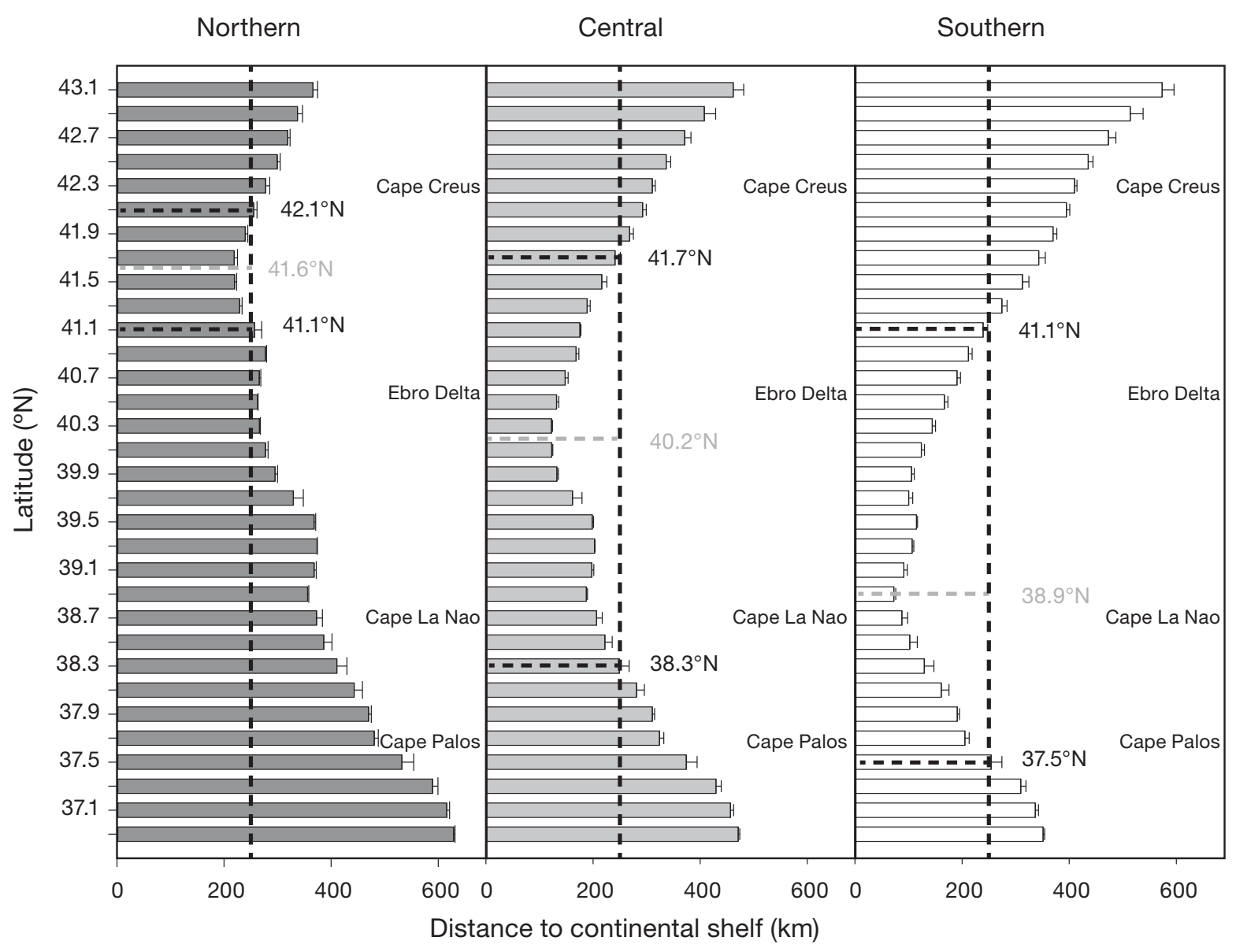

Fig. 3. Puffinus mauretanicus. Mean $( \pm \mathrm{SE})$ distance between northern, central and southern populations and the limit of the continental shelf at a depth of $200 \mathrm{~m}$ along the latitudinal axis of the study area. Only CEL was included as representative of central populations given the relatively short distance between CEL and CON. The centre of the potential foraging ground was identified by the minimum distance (grey dashed line) and its range by the limit of the search radius of $250 \mathrm{~km}$ (black dashed lines). See Fig. 1 for locations of geographic reference points listed

Oceanographically, each breeding population exploited distinct potential foraging grounds, highlighted by chl a (Kruskal-Wallis test, $H_{2,669}=86.29, \mathrm{p}<0.001$ ), SST $\left(H_{2,669}=134.63, \mathrm{p}<0.001\right)$ and its gradient $\left(H_{2,669}\right.$ $=18.23, \mathrm{p}<0.001)$, and bathymetry $\left(H_{2,669}=27.21, \mathrm{p}<\right.$ $0.001)$ and its spatial gradient $\left(H_{2,669}=12.82, \mathrm{p}<0.01\right.$; Fig. 6). However, the chl a gradient did not differ among potential foraging grounds. Oceanographic conditions of each potential foraging ground differed showing a latitudinal gradient; the northern population exploited richer (high chl a concentration), colder and deeper waters compared to central and southern populations.

When linking SIs with oceanographic variables, we did not consider the chl a gradient since it did not differ among potential foraging grounds. The uncorrelated variable for explaining both SIs was only chl $a$ and we developed all possible combinations of models. We found that only the linear positive effect of chl a was im- portant in explaining the observed variation in $\delta^{15} \mathrm{~N}$ and $\delta^{13} \mathrm{C}$ values (models with lowest $\mathrm{AIC}_{\mathrm{c}}$ value; Table 4). Individuals of northern, central and southern populations exploited potential foraging grounds of higher, intermediate and lower chl a values, respectively (Table 5, Fig. 6 and Fig. S3 in Supplement 3 at www.intres.com/articles/suppl/m429p291_supp.pdf).

\section{DISCUSSION}

By comparing SI values, habitat models and oceanography, we provided important information on the foraging ecology of the Balearic shearwater. SI values of shearwaters varied with latitude in relation to the location of the breeding site, which suggested that each population exploited geographically separated foraging grounds; birds from the northern population had lower $\delta^{15} \mathrm{~N}$ and $\delta^{13} \mathrm{C}$ values, followed by intermediate 


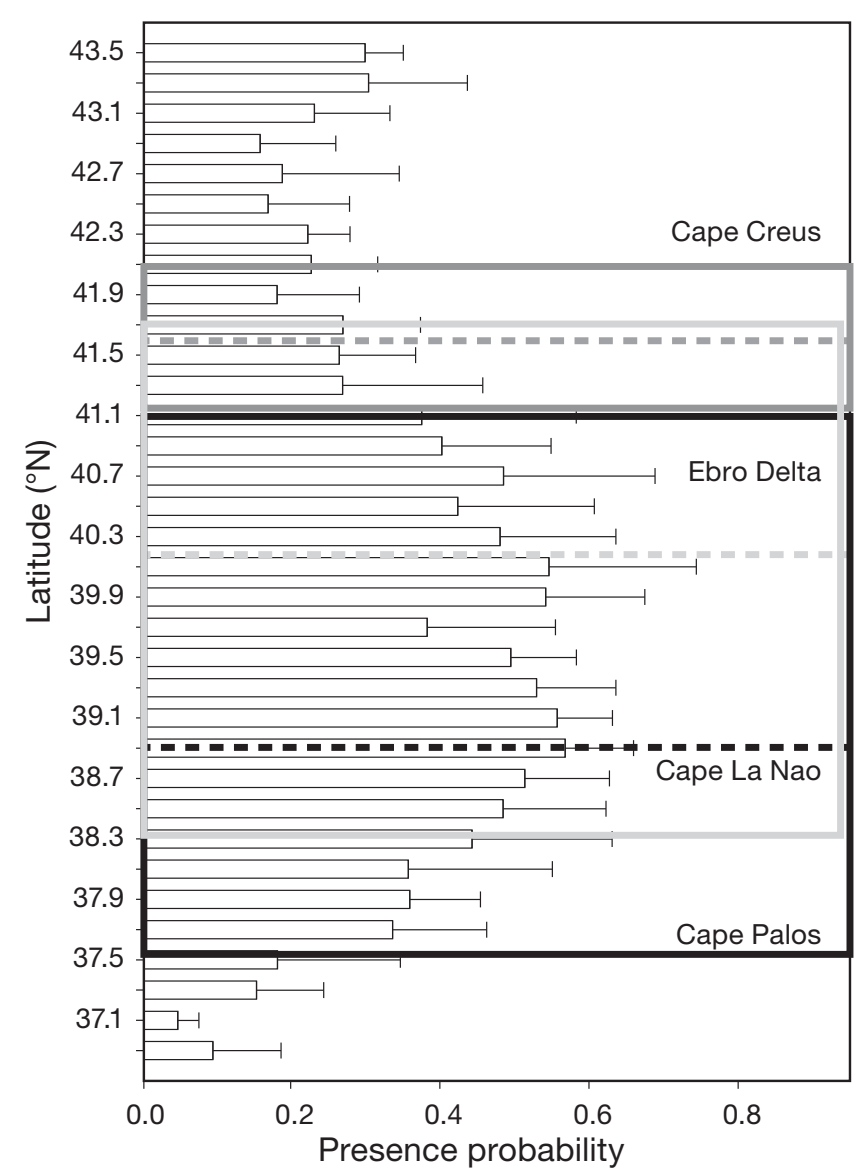

Fig. 4. Puffinus mauretanicus. Mean $( \pm \mathrm{SE})$ probability presence of Balearic shearwaters within the Iberian continental shelf along the latitudinal axis of the study area. The centre (dashed line) and range (solid line) of the potential foraging grounds are indicated for northern (dark grey), central (light grey) and southern (black) populations. See Fig. 1 for location of geographic reference points listed

and higher values in central and southern populations, respectively. Both $\delta^{13} \mathrm{C}$ and $\delta^{15} \mathrm{~N}$ values have been used to distinguish foraging habitats of seabirds (Forero et al. 2004, Cherel \& Hobson 2007). Intraspecific isotopic variability can largely be attributed to differences in diet composition or exploitation of different foraging grounds that have different baseline isotopic values (Rubenstein \& Hobson 2004, Forero et al. 2005, Gómez-Díaz \& González-Solís 2007, Votier et al. 2010). Several pieces of evidence point to varying isotopic baselines (i.e. oceanographic conditions) among foraging grounds rather than differences in diet. First, the main 2 trophic resources of Balearic shearwaters (e.g. small pelagic fish and trawling discards; see Navarro et al. 2009, Käkelä et al. 2010) are widely distributed throughout the western Mediterranean basin (Carbonell et al. 1998, Bellido et al. 2008). Even if the patterns of movement of Balearic shearwaters are influenced by trawling activity (Bartumeus et al. 2010), the spatial location of their foraging grounds might not change due to the overlap of marine productivity hotspots (including small pelagic fish) and main fishing grounds along the Iberian continental shelf (Demestre et al. 1988, Estrada 1996). Second, isotopic values of small pelagic fishes change along the Iberian continental shelf (Ramos et al. 2009), which may be explained by the natural geographic variation in the baseline isotopic values relating to water properties (e.g. Barnes et al. 2009, Graham et al. 2010). In fact, the western Mediterranean is characterised by a latitudinal gradient in chl a and SST values of oceanic waters (i.e. more productive and cooler in the Gulf of Lions than in Cape Palos), whereas coastal waters show productivity hotspots in Cape Creus, Ebro Delta and Cape La Nao (Sabatés et al. 2006, Bellido et al. 2008, Gordoa et al. 2008). Moreover, SI values of other marine top predators also show overall latitudinal gradients explained by the exploitation of different water masses along the Southern Ocean, showing increasing negative $\delta^{13} \mathrm{C}$ values with decreasing SST and lower nutrient availability (Bailleul et al. 2010).

Oceanographic habitat models of shearwaters not only supported our hypothesis of geographical segregation of foraging grounds, they also helped to better define the most likely potential foraging grounds of northern, central and southern populations. Potential foraging grounds were influenced by the main mesoscale oceanographic features enhancing ocean productivity in the western Mediterranean basin (Louzao et al. 2006a), since all 3 potential foraging grounds overlapped with maximums of both chl $a$ and SST spatial gradients. Overall, the marine Northern Current flows along the continental slope from the Ligurian Sea to the south of the Eivissa Channel, transporting nutrient-rich waters southwards (Millot 1999, Arnau et al. 2004). Specifically, the narrow potential foraging ground of the northern population could be explained by the mesoscale eddies (Arnau et al. 2004) and submarine canyons (Palanques et al. 2005), which increase localised productivity and aggregate small pelagic fishes in a predictable manner (Bellido et al. 2008). The wider latitudinal range of the central population was centred at the Ebro Delta, where river run-off and cold winds enrich surface waters and make this area one of the most productive regions - a major fish spawning area, especially for small pelagic fishes - and where important fishing fleets operate within the western basin (Estrada 1996, Sabatés 1990, Coll et al. 2006, Bellido et al. 2008). The potential foraging ground of the southern population was centred in Cape La Nao probably due to the presence of important frontal structures related to confluence of different water masses of Atlantic and Mediterranean origin (Fig. 5, Millot 1999). 

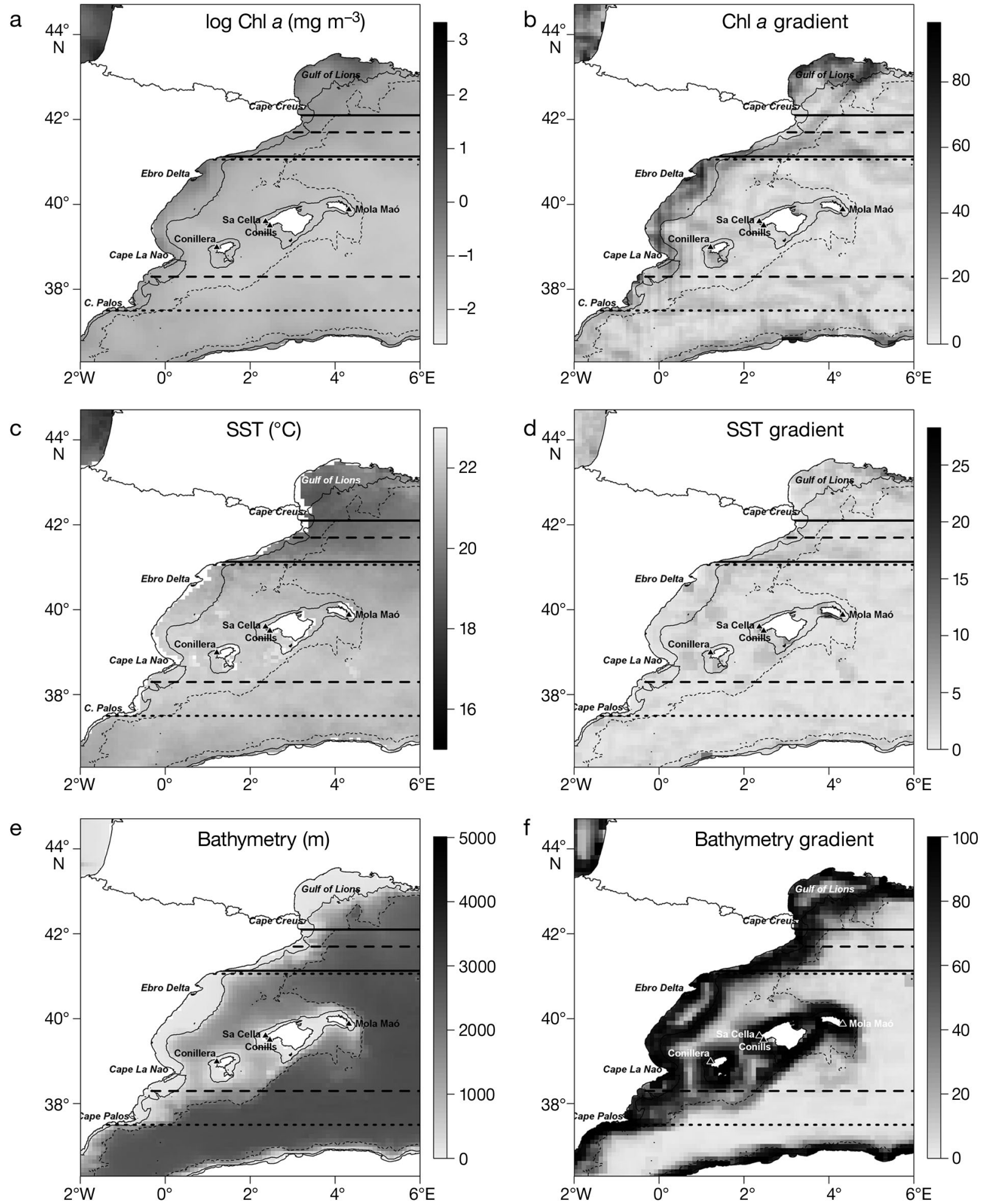

Fig. 5. Puffinus mauretanicus. Oceanographic characterisation of the study area in March 2003 showing (a) chl a concentration, (b) chl a gradient, (c) SST, (d) SST gradient (m), (e) bathymetry and (f) bathymetry gradient relative to the limits of the potential foraging grounds of northern (solid black line), central (dashed black line) and southern (dotted black line) populations. Spatial gradients are estimated within a surrounding $3 \times 3$ cell $\left(0.1^{\circ} \times 0.1^{\circ}\right)$ grid using a moving window. See 'Materials and methods: Oceanographic characterisation of potential foraging ground' for further explanation 

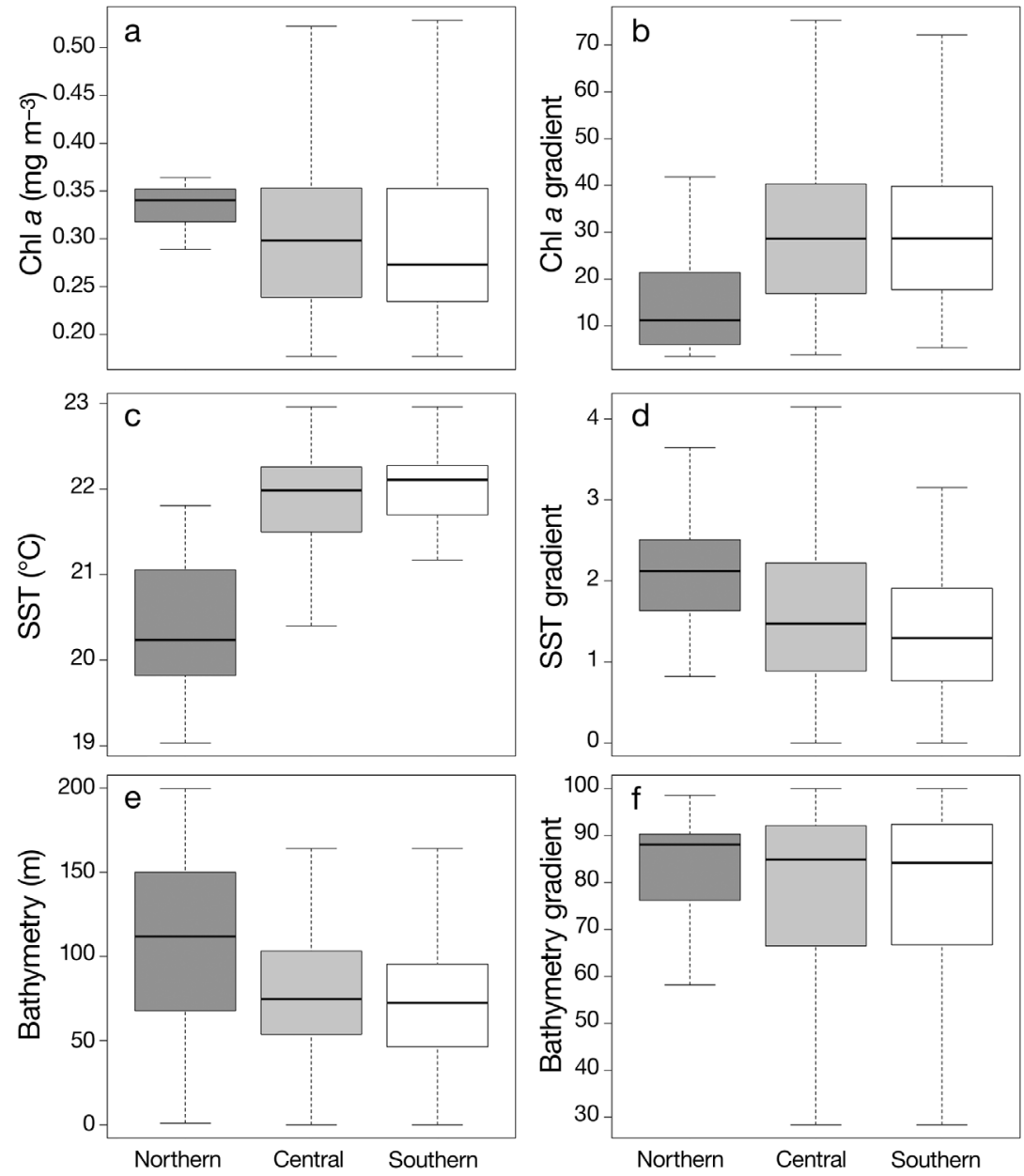

Fig. 6. Puffinus mauretanicus. Oceanographic characterisation of the potential foraging grounds of northern, central and southern populations over the Iberian continental shelf indicated by box plots of median (thick black horizontal lines), $25-75 \%$ interquartile range (horizontal limits of boxes), and non-outlier range (horizontal limits of dashed lines): (a) chl a concentration, (b) chl a gradient,

(c) SST, (d) SST gradient, (e) bathymetry, and (f) bathymetry gradient

Breeding Balearic shearwaters likely use the same foraging grounds year after year as the western Mediterranean is characterised by a relatively stable coastal circulation, and overall chl a values may not differ greatly between years (Gordoa et al. 2008). In fact, the location of resources at large and intermediate scales appears reasonably predictable for pelagic seabirds over long time periods in the Mediterranean because they associate to the same mesoscale features along the Iberian continental shelf during different years (Arcos \& Oro 2002, Abelló et al. 2003, Louzao et al. 2006a, Louzao et al. 2009). The use of tracking devices may link foraging trip characteristics to fitness parameters such as breeding performance. Individuals that have to travel longer distances may experience lower reproductive success (Boersma \& Rebstock 2009).

Our comprehensive study also provided important information for management strategies to assist the conservation of this shearwater; we estimated for the first time the spatial location of the potential foraging grounds of northern, central and southern populations along the Iberian continental shelf. Given the delicate status of this population, marine zoning measures may greatly benefit the conservation of the Balearic shearwater by extending protective measures beyond the breeding sites. In fact, potential foraging grounds, such as those centred in

Table 4. Puffinus mauretanicus. Modelling $\delta^{15} \mathrm{~N}$ and $\delta^{13} \mathrm{C}$ values in blood of Balearic shearwaters to randomly assigned oceanographic variables based on GLMs. Models were compared and ranked based on their Akaike Information Criteria values corrected for small sample sizes $\left(\mathrm{AIC}_{\mathrm{c}}\right)$. Selected models are in bold. CHL: chl $a_{i}$ np: number of parameters estimated in the model

\begin{tabular}{|lrr|}
\hline Model & $\mathrm{np}$ & $\mathrm{AIC}_{\mathrm{c}}$ \\
\hline$\delta^{15} \mathrm{~N}$ & & \\
CHL & $\mathbf{2}$ & $\mathbf{9 7 . 5 8}$ \\
$\mathrm{CHL}+\mathrm{CHL}^{2}$ & 3 & 100.28 \\
Null & 1 & 102.04 \\
& & \\
$\delta^{13} \mathrm{C}$ & & $\mathbf{5 4 . 2 1}$ \\
CHL & $\mathbf{2}$ & 57.79 \\
$\mathrm{CHL}+\mathrm{CHL}^{2}$ & 3 & 65.14 \\
Null & 1 & \\
\hline
\end{tabular}

Cape Creus, Ebro Delta and Cape La Nao, could constitute a network of Marine Protected Areas (MPAs), and they have been recently identified as marine Important Bird Areas (IBAs) for the conservation of the western Mediterranean seabird community (Arcos et al. 2009). Within the potential foraging grounds, other more diffuse protective measures could be implemented, such as a compulsory fishery observer program to record potential bycatch in bottom longline fisheries and the study of potential impacts of wind farms over the continental shelf region. Evidence exists that Balearic shearwaters are incidentally caught in bottom longline, (Arcos et al. 2008, ICES 2008, Louzao et al. in press), and trawling activity could influence this probability (Laneri et al. 2010). Moreover, reducing fisheries bycatch in bottom longlines is still the key factor in the conservation of the 
Table 5. Puffinus mauretanicus. Summary statistics of the selected GLM model in Table 4 for explaining $\delta^{15} \mathrm{~N}$ and $\delta^{13} \mathrm{C}$ values in blood of adult Balearic shearwaters to randomly assigned oceanographic variables. CHL: chl a

\begin{tabular}{|lcccc|}
\hline Variable & $\begin{array}{c}\text { Estimated } \\
\text { parameter }\end{array}$ & SE & $t$ & $\operatorname{Pr}(>|t|)$ \\
\hline$\delta^{15} \mathrm{~N}$ & & & & \\
Intercept & 9.79 & 0.11 & 90.55 & $<0.001$ \\
CHL & -0.33 & 0.11 & -3.03 & $<0.001$ \\
& & & & \\
$\delta^{13} \mathrm{C}$ & & 0.06 & -293.79 & $<0.001$ \\
Intercept & -18.96 & 0.06 & -4.16 & $<0.001$ \\
CHL & -0.27 & & & \\
\hline
\end{tabular}

species (Oro et al. 2004, Louzao et al. 2006b), in addition to removing threats related to introduced predators in some accessible colonies. Unfortunately, not much effort has been directed at obtaining detailed local information on seabird mortality at national or European levels and, in turn, the spatio-temporal window of the interaction between bottom longlines and Balearic shearwaters is not well known. Thus, we emphasize the urgent need to assess the interaction of shearwaters with longline fishery within their foraging grounds during breeding in the western Mediterranean, and also recommend assessment during the post-breeding period along the Mediterranean and North Atlantic.

Acknowledgements. We are especially grateful to I. Afán, J. Calvo, E. Cardona, R. Escandell, R. Fernández-Graña, O. Martínez, M. McMinn, A. Rodríguez, C. Santana, and R. Triay for their help during the fieldwork. V. Rodríguez and M. Bauzà helped with molecular sex identification. J.M. Arcos and G. Bortolotti provided invaluable comments to first versions of this manuscript. Permits were provided by Conselleria de Medi Ambient (Govern de les Illes Balears), Cabrera National Park, the Military Government of Menorca, Parc Natural de Cala d'Hort and Parc Natural de Ses Salines. This study was funded by Govern de les Illes Balears, DISCBIRD (QLRT-2000-00839) and LIFE projects (European Commission) and the Spanish Ministries of Education and Science (ref. BOS2003-01960 and REN2002-00450) and of the Environment (ref. 024A/2002). M.L. was supported by fellowships from Govern de les Illes Balears and Institut Menorquí d'Estudis, as well as by a postdoctoral contract of the Spanish Ministry of Education and Science (ref. EX-2007-1148) and Marie Curie Individual Fellowship (PIEF-GA-2008-220063). J.N. was supported by a researcher contract from of the Spanish Ministry of Science and Innovation (Juan de la Cierva program). M.G.F. and M.G. by Ramon y Cajal and I3P contracts, respectively, of the Spanish Ministry of Education and Science. Experiments comply with the current laws of the country in which the experiments were performed. We acknowledge the editor and 4 anonymous referees for their help with bringing the manuscript to its final state.

\section{LITERATURE CITED}

Abelló P, Arcos JM, Gil de Sola L (2003) Geographical patterns of seabird attendance to a research trawler along the Iberian Mediterranean coast. Sci Mar 67:69-75

Arcos JM (compiler) (2011) International species action plan for the Balearic shearwater, Puffinus mauretanicus. SEO/ BirdLife \& BirdLife International. Available at http://ec. europa.eu/environment/nature/conservation/wildbirds/ action_plans/per_species_en.htm

Arcos JM, Oro D (2002) Significance of fisheries discards for a threatened Mediterranean seabird, the Balearic shearwater Puffinus mauretanicus. Mar Ecol Prog Ser 239:209-220

Arcos JM, Louzao M, Oro D (2008) Fisheries ecosystem impacts and management in the Mediterranean: seabirds point of view. In: Nielsen JL, Dodson JJ, Friedland K, Hamon TR, Musick J, Verspoor E (eds) Reconciling fisheries with conservation. Proc 4th World Fish Cong. American Fisheries Society, Bethesda, MD, p 1471-1479

Arcos JM, Bécares J, Rodrígez B, Ruiz A (2009) Áreas importantes para la conservación de las aves marinas en España. LIFE04NAT/ES/000049-Sociedad Española de Ornitología (SEO/Bird-Life), Madrid

Arnau P, Liquete C, Canals M (2004) River mouth plume events and their dispersal in the northwestern Mediterranean Sea. Oceanography 17:22-31

Bailleul F, Authier M, Ducatez S, Roquet F, Charrassin JB, Cherel Y, Guinet C (2010) Looking at the unseen: combining animal bio-logging and stable isotopes to reveal a shift in the ecological niche of a deep diving predator. Ecography 33:709-719

Barnes C, Jennings S, Barry JT (2009) Environmental correlates of large-scale spatial variation in the $\delta^{13} \mathrm{C}$ of marine animals. Est Coast Shelf Sci 81:368-374

Bartumeus F, Giuggioli L, Louzao M, Bretagnolle V, Oro D, Levin S (2010) Fishery discards impact on seabird movement patterns at regional scales. Curr Biol 20:215-222

- Bellido JM, Brown AM, Valavanis VD, Giráldez A, Pierce GJ, Iglesias M, Palialexis A (2008) Identifying essential fish habitat for small pelagic species in Spanish Mediterranean waters. Hydrobiologia 612:171-184

BirdLife International (2008) Species factsheet: Puffinus mauretanicus. Available at: www.birdlife.org/datazone/ speciesfactsheet.php?id=30026

Boersma PD (2008) Penguins as marine sentinels. Bioscience 58: 597-607

Boersma PD, Rebstock GA (2009) Foraging distance affects reproductive success in Magellanic penguins. Mar Ecol Prog Ser 375:263-275

Carbonell A, Martín P, de Ranieri S \& WEDIS team 1 (1998) Discards of the western Mediterranean trawl fleets. Rapp Comm Int Mer Médit 35:392-393

- Cherel Y, Hobson KA (2007) Geographical variation in carbon stable isotope signatures of marine predators: a tool to investigate their foraging areas in the Southern Ocean. Mar Ecol Prog Ser 329:281-287

Coll M, Palomera I, Tudela S, Sarda F (2006) Trophic flows, ecosystem structure and fishing impacts in the South Catalan Sea, Northwestern Mediterranean. J Mar Syst 59:63-96

Demestre M, Lleonart J, Martín P, Recasens L, Sánchez P (1988) La pesca en Cataluña. FAO rapport sur les pêches 395: 101-103

Deuel HJ (1955) Biochemistry, digestion, absorption, transport, and storage. The lipids, Vol 2. Interscience, New York, NY

Estrada M (1996) Primary production in the northwestern Mediterranean. Sci Mar 60:55-64

Forero MG, Hobson KA (2003) Using stable isotopes of nitrogen and carbon to study seabird ecology: applications in the Mediterranean seabird community. Sci Mar 67:23-32 
Forero MG, Bortolotti GR, Hobson KA, Donázar JA, Bertellotti M, Blanco G (2004) High trophic overlap within the seabird community of Argentinean Patagonia: a multiscale approach. J Anim Ecol 73:789-801

Forero MG, González-Solís J, Hobson KA, Donázar JA, Bertellotti M, Blanco G, Bortolotti GR (2005) Stable isotopes reveal trophic segregation by sex and age in the southern giant petrel in two different food webs. Mar Ecol Prog Ser 296: 107-113

Furness RW, Birkhead TR (1984) Seabird colony distributions suggest competition for food supplies during the breeding season. Nature 311:655-665

Gómez-Díaz E, González-Solís J (2007) Geographic assignment of seabirds to their origin: combining morphologic, genetic, and biogeochemical analyses. Ecol Appl 17:1484-1498

Gordoa A, Illas X, Cruzado A, Velásques Z (2008) Spatio-temporal patterns in the north-western Mediterranean from MERIS derived chlorophyll a concentration. Sci Mar 72: 757-767

- Graham BS, Koch PL, Newsome SD, McMahon KW, Aurioles D (2010) Using isoscapes to trace the movements and foraging behavior of top predators in oceanic ecosystems. In: West JB, Bowen GJ, Dawson TE, Tu KP (eds) Isoscapes: understanding movement, pattern and process on earth through isotope mapping. Springer-Verlag, New York, NY, p 299-318

> Grémillet D, Dell'Omo G, Ryan PG, Peters G, Ropert-Coudert Y, Weeks SJ (2004) Offshore diplomacy, or how seabirds mitigate intra-specific competition: a case study based on GPS tracking of Cape gannets from neighbouring colonies. Mar Ecol Prog Ser 268:265-279

Guilford TC, Meade J, Freeman R, Biro D and others (2008) GPS tracking of the foraging movements of Manx Shearwaters Puffinus puffinus breeding on Skomer Island, Wales. Ibis 150:462-473

> Guisan A, Zimmermann NE (2000) Predictive habitat distribution models in ecology. Ecol Model 135:147-186

> Hobson KA, Clark RG (1992) Assessing avian diets using stable isotopes II: factors influencing diet-tissue fractionation. Condor 94:189-197

Hunt GL, Eppley ZA, Schneider DC (1986) Reproductive performance of seabirds: the importance of population and colony size. Auk 103:306-317

ICES (International Council for the Exploration of the Sea) (2008) Report of the Working Group on Seabird Ecology (WGSE). 10-14 March 2008, Lisbon, Portugal. ICES CM 2008/LRC:05. ICES, Copenhagen. Available at www.ices. $\mathrm{dk} / \mathrm{reports} / \mathrm{LRC} / 2008 /$ WGSE/WGSE2008.pdf

> Inger R, Bearhop S (2008) Applications of stable isotope analyses to avian ecology. Ibis 150:447-461

> Käkelä R, Käkelä A, Martínez-Abraín A, Sarzo B and others (2010) Fatty acid signature analysis confirms foraging resources of a globally endangered Mediterranean seabird species: calibration test and application to the wild. Mar Ecol Prog Ser 398:245-258

> Laneri K, Louzao M, Martínez-Abraín A, Arcos JM and others (2010) Trawling regime influences longline seabird bycatch in the Mediterranean: new insights from a small-scale fishery. Mar Ecol Prog Ser 420:241-252

> Louzao M, Hyrenbach KD, Arcos JM, Abelló P, Gil de Sola L, Oro D (2006a) Oceanographic habitat of an endangered Mediterranean Procellariiform: implications for marine protected areas. Ecol Appl 16:1683-1695

> Louzao M, Igual JM, McMinn M, Aguilar JS, Triay R, Oro D (2006b) Small pelagic fish, trawling discards and breeding performance of the critically endangered Balearic shearwater: improving conservation diagnosis. Mar Ecol Prog Ser 318:247-254

> Louzao M, Bécares J, Rodríguez B, Hyrenbach KD, Ruiz A,
Arcos JM (2009) Combining vessel-based surveys and tracking data to identify key marine areas for seabirds. Mar Ecol Prog Ser 391:183-197

Louzao M, Arcos JM, Laneri K, Martínez-Abraín A and others (in press) Evidencias de la captura incidental de pardela balear en el mar. Actas del VI Congreso del GIAM

Millot C (1999) Circulation in the Western Mediterranean Sea. J Mar Syst 20:423-442

- Navarro J, Louzao M, Igual JM, Oro D and others (2009) Seasonal changes in the diet of a critically endangered seabird and the importance of trawling discards. Mar Biol 156: 2571-2578

Orians GH, Pearson NE (1979) On the theory of central place foraging theory. In: Horn DJ, Mitchell RM, Stairs GR (eds) Analysis of ecological systems. Ohio State University Press, Columbus, $\mathrm{OH}$

Oro D, Aguilar JS, Igual JM, Louzao M (2004) Modelling demography and extinction risk in the endangered Balearic shearwater. Biol Conserv 116:93-102

Palanques A, García-Ladona E, Gomis D, Martín J and others (2005) General patterns of circulation, sediment fluxes and ecology of the Palamós (La Fonera) submarine canyon, northwestern Mediterranean. Prog Oceanogr 66:89-119

> Phillips RA, Bearhop S, Mcgill RAR, Dawson DA (2009) Stable isotopes reveal individual variation in migration strategies and habitat preferences in a suite of seabirds during the nonbreeding period. Oecologia 160:795-806

Powell CDL (2009) Foraging movements and the migration trajectory of flesh-footed shearwaters Puffinus carneipes from the south coast of western Australia. Mar Ornithol 37:115-120

Quinn GP, Keough MJ (2002) Experimental design and data analysis for biologists. Cambridge University Press, Cambridge

R Development Core Team (2009) R: a language and environment for statistical computing. R Foundation for Statistical Computing, Vienna

Ramos R, Ramírez F, Sanpera C, Jover L, Ruiz X (2009) Feeding ecology of yellow-legged gulls Larus michahellis in the western Mediterranean: a comparative assessment using conventional and isotopic methods. Mar Ecol Prog Ser 377:289-297

Rubenstein DR, Hobson KA (2004) From birds to butterflies: animal movement patterns and stable isotopes. Trends Ecol Evol 19:256-263

Ruiz A, Martí R (eds) (2004) La pardela balear. SEO/BirdLifeConselleria de Medi Ambient del Govern de les Illes Balears, Madrid

Sabatés A (1990) Distribution pattern of larval fish populations in the Northwestern Mediterranean. Mar Ecol Prog Ser 59:75-82

Sabatés A, Martín P, Lloret J, Raya V (2006) Sea warming and fish distribution: the case of the small pelagic fish, Sardinella aurita, in the western Mediterranean. Glob Change Biol 12:2209-2219

Votier SC, Bearhop S, Witt MJ, Inger R, Thompson D, Newton J (2010) Individual responses of seabirds to commercial fisheries revealed using GPS tracking, stable isotopes and vessel monitoring systems. J Appl Ecol 47:487-497

Warham J (1990) The petrels: their ecology and breeding systems. London Academic Press, London

Williams BK, Nichols JD, Conroy MJ (2002) Analysis and management of animal populations. Academic Press, San Diego

Young LC, Vanderlip C, Duffy DC, Afanasyev V, Shaffer SA (2009) Bringing home the trash: Do colony-based differences in foraging distribution lead to increased plastic ingestion in Laysan albatrosses? PLoS ONE 4:e7623

Zuur AF, Ieno EN, Smith GM (2007) Analysing ecological data. Springer, New York, NY 